\title{
A HANDBOOK OF \\ TROPICAL PAEDIATRICS
}




\author{
Macmillan Tropical Community Health Manuals \\ General Editor: Dr J. Grant, London School of Hygiene and Tropical Medicine
}

This series has been set up specifically to meet the needs of trainee and practising medical personnel in the tropical and sub-tropical developing countries. Some of the books will appeal to others involved in Community work-e.g. school teachers, public health inspectors, environmental health officers, and even literate parents. Early on there will be heavy concentration on aspects of care offering best prospects for improved standards of preventative treatment and therefore health in the community. Inevitably there will be strong emphasis on infant, child and mother care, as infants and children account for up to half the total population in some tropical developing countries, and more than half of the presentations for treatment.

Most titles will be short practical books written for trainee and practising doctors, nurses, auxiliaries, medical officers and assistants and other grades of health-care personnel engaged in frontline health-care delivery, often in small rural centres and sub-centres.

Other titles by G. J. Ebrahim in the Macmillan Tropical Community Health Manuals Series

Breast Feeding: the Biological Option

cased ISBN 978-0-333-23802-8

Child Care in the Tropics paper ISBN 978-0-333-23803-5

cased ISBN 978-0-333-24038-0 paper ISBN 978-0-333-25361-8

Practical Mother and Child Health in Developing Countries

cased ISBN 978-0-333-24111-0 paper ISBN 978-0-333-25363-2

Care of the Newborn in Developing Countries cased ISBN 978-0-333-24112-7 paper ISBN 978-0-333-25362-5

The paperback edition of $A$ Handbook of Tropical Paediatrics is published at a specially low price as a result of a subsidy provided by the Catholic Fund for Overseas Development. 


\section{A HANDBOOK OF TROPICAL PAEDIATRICS}

G. J. EBRAHIM

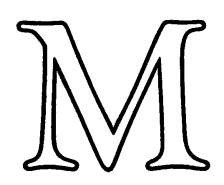

Published with the support of the Catholic Fund for Overseas Development 
(c) G. J. Ebrahim 1978

Softcover reprint of the hardcover 1st edition 1978

All rights reserved. No part of this publication may be reproduced or transmitted, in any form or by any means, without permission.

First published 1978 by

THE MACMILLAN PRESS LTD

London and Basingstoke

Associated companies in Delhi Dublin

Hong Kong Johannesburg Lagos Melbourne

New York Singapore and Tokyo

British Library Cataloguing in Publication Data

Ebrahim, G J

Handbook of tropical paediatrics - Revised ed.

- (Macmillan tropical community health manuals).

1. Pediatrics 2. Tropical medicine

I. Title

$618.9^{\prime} 2^{\prime} 000913 \quad$ RJ47

ISBN 978-0-333-25364-9 ISBN 978-1-349-15949-9 (eBook)

DOI 10.1007/978-1-349-15949-9

This boak is sold subject to the standard conditions of the Net Book Agreement.

The paperback edition of this book is sold subject to the condition that it shall not, by way of trade or otherwise, be lent, resold, hired out, or otherwise circulated without the publisher's prior consent in any form of binding or cover other than that in which it is published and without a similar condition including this condition being imposed on the subsequent purchaser. 


\section{Contents}

1 Growth 1

2 Motor, Mental and Social Development 8

3 Average Biochemical Standards 12

4 Biochemical Tests 15

5 Haematological Data 21

6 Nutrition and Dietetics 25

7 Water and Electrolytes 47

8 Common Emergencies 53

9 The Newborn 65

10 Infectious Diseases 71

Appendix I Drug Dosage in Tropical Diseases 75

Appendix II Dosage of Drugs in the Newborn Period 79

Appendix III Dosage of some Important Drugs $\quad 80$

Appendix IV Dosage of Principal Antibiotics and 84

Index 86 
To:

The Residents and Nursing Staff, Paediatric Department,

Muhimbili Hospital. 


\section{Preface}

The HANDBOOK OF TROPICAL PAEDIATRICS evolved out of the various regimens of treatment developed in the paediatric wards of the Muhimbili Hospital, Dar-es-Salaam. It was observed that in common with similar busy paediatric departments the quality of care tended to be better for day-time admissions as compared to children admitted at night or during week-ends. It became necessary to establish common standards of care for the guidance of interns and junior staff. These standards were further modified and simplified with experience. Facilities for investigation and treatment are naturally better in teaching hospitals as compared to regional and district hospitals and health centres. The various regimens were then further tried in these health institutions and modified in the light of the comments received.

In more recent years several Fellows of the UNICEF/WHOsponsored Course for Senior Teachers of Child Health have used the above regimens in different centres in the developing world. Based on their comments the regimens have been revised and re-written and several improvements have been made.

A HANDBOOK OF TROPICAL PAEDIATRICS is one of a set of four manuals which together comprise the Health Centre Set. Each manual is intended for a specific member of the health team. The Handbook is meant for the "doctor" in the health team. It is hoped that the manuals of the Health Centre Set will help to raise the standards of teaching and care of children in the rural areas of the developing world. 


\section{Acknowledgements}

The section on nutrition is based on the work of Dr Leslie Burgess, WHO inter-country consultant in nutrition, and Mrs Ann Burgess. 